application of electron optical techniques to the elucidation of a wide range of problems; and this work commenced at Cambridge in the Research Laboratory for the Physics and Chemistry of Surfaces, Department of Physical Chemistry, with a study by electron diffraction of the orientation of long-chain hydrocarbon compounds on metal surfaces. He has applied electron optical techniques to metallurgical problems, and more recently he has adapted a transmission electron microscope for use as a reflexion instrument and investigated a wide range of surface phenomena. Dr. Menter is at present working in the Tube Investments Research Laboratories, Hinxton Hall.

\section{Royal Society of Edinburgh : New Fellows}

THe following have been elected Fellows of the Royal Society of Edinburgh: Mr. W. Anderson, district geologist, Geological Survey of Great Britain; Dr. D. J. Bell, senior principal scientific officer, Poultry Research Centre, Edinburgh; Dr. W. A. P. Black, head of the Chemical Division of the Institute of Seaweed Research, Musselburgh; Dr. P. H. Davis, lecturer in the Department of Botany, University of Edinburgh; Dr. W. A. Fairbairn, lecturer in the Department of Forestry, University of Edinburgh ; Dr. D. J. Finney, reader in statistics, University of Aberdeen; Dr. P. G. Fothergill, lecturer in botany, University of Durham ; Principal T. M. Knox, University of St. Andrews; Mr. J. Kyles, lecturer in the Department of Natural Philosophy, University of Edinburgh; Prof. A. M. Macbeath, Department of Mathematics, Queen's College, Dundee; Mr. D. H. McIntosh, superintendent of the Observatory, Eskdalemuir, Dumfriesshire; Sir James Miller, managing director of James Miller and Partners, Ltd.; Dr. N. Miller, senior lecturer in radiochemistry, University of Edinburgh ; Dr. G. H. Mitchell, district geologist, Geological Survey of Great Britain (Edinburgh Office); Dr. R. L. Mitchell, head of the Department of Spectrochemistry, Macaulay Institute for Soil Research, Aberdeen; Prof. S. D. Nisbet, Department of Education, University of Glasgow ; Dr. A. E. Oxford, head of the Department of Microbiology, Rowett Research Institute, Aberdeen; Dr. H. S. A. Potter, senior lecturer in the Department of Mathematics, University of Aberdeen; Mr. K. A. Pyefinch, Brown Trout Research Laboratory, Pitlochry ; Prof. R. A. Rankin, Department of Mathematics, University of Glasgow; Dr. G. A. Reay, superintendent of the Torry Research Station, Aberdeen; Prof. G. J. Romanes, Department of Anatomy, University of Edinburgh ; Prof. A. B. Stewart, Department of Agriculture, University of Aberdeen; Mr. H. B. Sutherland, senior lecturer in civil engineering, University of Glasgow ; and Dr. D. Taylor, lecturer in chemistry, University of Edinburgh.

\section{V. Boys (1855-1944): Centenary Exhibition in London}

THE Science Museum, London, is commemorating the centenary of the birth of Sir Charles Vernon Boys $(1855-1944)$ by a special display of instruments drawn from the permanent collections. The exhibition will be open for a period of three months, commencing on March 15, Boys's birthday. Of his manifold activities in the field of experimental physics, Boys is probably best remembered for his work on the production and properties of exceedingly fine quartz fibres. The fibres were used in the construction of a very sensitive radio-micrometer which, aided by a reflecting telescope, was capable of detecting radiation as feeble as that from the flame of a candle at a distance of almost three miles. The elastic properties of quartz fibres were also utilized by Boys in designing a torsion balance with which he determined the Newtonian constant of gravitation and the mean density of the earth with an accuracy previously unattainable. In addition to the original radiomicrometer and gravitational apparatus, the exhibits include Boys's lightning camera, his gas calorimeter and a number of mathematical instruments.

\section{Optimum Use of Scientific Workers in Great Britain}

IN announcing in the House of Commons on March 10 the Government's acceptance of the recommendations of the Burnham Committee for the payment of special allowances to teachers of advanced work, Sir David Eccles, the Minister of Education, said that at the request of the Government the Federation of British Industries has sent a circular to the seven thousand individual firms and three hundred trade associations comprising its membership asking them to exercise restraint in bidding against the schools for science graduates. The circular states that, in discussions with the Government on the shortage of science teachers, it was pointed out to the Federation that a hopeless situation would arise if the increased remuneration for teachers was countered by a corresponding raising of salary levels by industry. The Federation agreed to put this point to its members, and the circular suggests that in this connexion firms could also review the use they make of scientific staff so as to reserve such staff for the really essential work for which they are best fitted. It is suggested that, in addition, some relief could be obtained by retaining scientific staff beyond the normal retiring age and that, if firms could help to encourage greater numbers of suitable and able boys to remain at school for a further period, both industry and the schools would ultimately benefit from an increased number of science graduates. The circular also states that the Government is reviewing the whole question of scientific workers in the public service so as to ensure that the best and most economical use is made of them in the national interest.

\section{Chalk Lime and Allied Industries' Research Association}

THE first general meeting of the Chalk Lime and Allied Industries' Research Association was held on March 9 in the Association's offices at Hanover House, 73-78 High Holborn, London. The preliminary work leading to the establishment of this, the latest of the research associations to be formed under the ægis of the Department of Scientific and Industrial Research, was done by the members of the Southern Lime Association. As indicated by its title, the new Association will conduct co-operative research for the chalk lime and allied industries. At the meeting, Mr. W. L. Clarke was elected chairman of the Association and Mr. M. W. Hall as vicechairman. Mr. G. E. Bessey has been appointed director of research and has already taken up his appointment. Mr. Bessey was previously director of research of the Research Council of the British Whiting Federation and before 1949 was on the staff of the Building Research Station. Negotiations are 